\title{
SKETCH-UP
}

\section{Southern Ocean mixing}

Nat. Geosci. http://dx.doi.org/10.1038/ngeo3053 (2017)

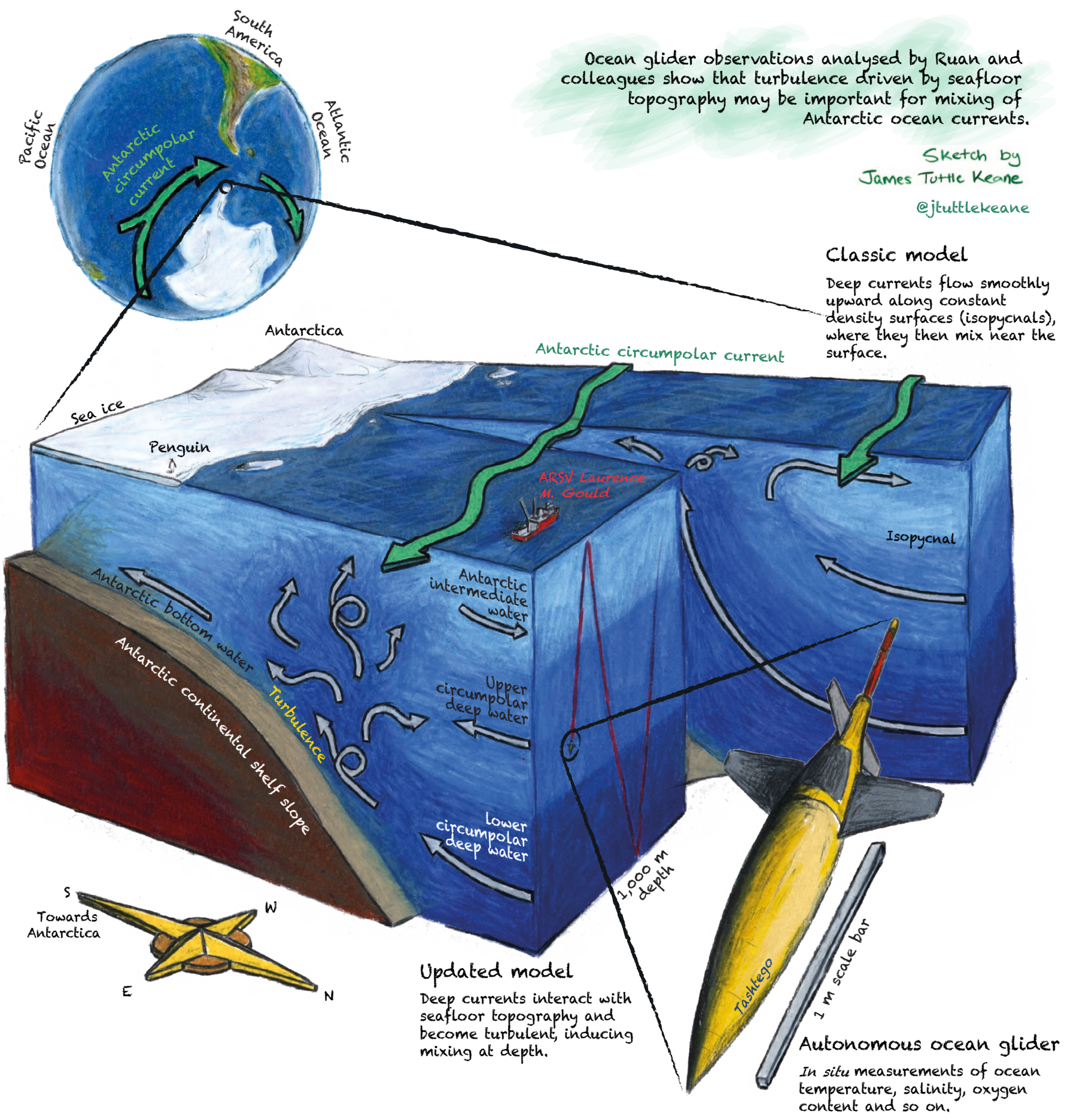

Published online: 30 October 2017 